\title{
MONOCLONAL ANTIBODIES AGAINST KERATINS BIND TO \\ INTERCALATED DUCT AND DUCTAL BASAL CELLS OF NORMAL SALIVARY GLANDS IN PARAFFIN SECTIONS
}

\author{
Yoshiaki TAKAI*, Kazuo YAMADA*, Hiroyuki SHINOHARA*, \\ TADASHI ORITO*, KOUJI TSUKITANI** \\ AND MASAHIKo MORI* \\ Department of Oral Surgery ${ }^{*}$, Asahi University School of Dentistory, Hozumi-cho, \\ Motosu-gun, Gifu, 501-02 and Department of Dentistry**, Kyoto Prefectural \\ University of Medicine, Kawaramachi-Hirokoji, \\ Kamigyo-ku, Kyoto 602
}

Received for publication August 17, 1988, in revised form November 9, 1988 and re-revised form November 28, 1988

\begin{abstract}
Intercalated duct cells and ductal basal cells in the salivary glands were suggested to be probable progenitor cells of salivary gland tumors. Different monoclonal anti-keratin antibodies (KL1, PKK1, PKK2, PKK3, RGE53, K4.62, K8.12, K8.13, K8.60, RPN1160, RPN1161, RPN1162, RPN1163, RPN1164, RPN1165, RPN1166) and polyclonal anti-keratin antiserum (TK) were tested on paraffin sections of Carnoy's- and formalin-fixed normal salivary gland tissues (parotid and submandibular glands). Monoclonal keratin antibodies could detect nos. $1,5,6,7,8,10,11,13,16,17,18$, and 19 keratins. Intercalated duct cells of normal salivary glands displayed positive staining with monoclonal antibodies KL1, K4.62, K8.12, K8.13, K8.60, RPN1160, and RPN1164. Ductal basal cells revealed positive staining with PKK1 (nos. 19 or 18, 8) (Carnoy's fixed section), and K8.12 (nos. 16, 13), K4.62 (no. 19), RPN1165 (no. 19) keratins, which bind to nos. $19,18,16,13,8$. Intercalated duct cells contained wide spectrum keratins. Keratin stainings (nos. 19 or 16, 13) of ductal basal cells in formalin fixed sections suggested nos. $19,16,13$ proteins to be some marker for progenitor cells of salivary gland tumors.
\end{abstract}

Several types of monoclonal antibodies for keratin polypeptides have been reported to specifically react with single keratins or with a limited number and with keratins of different molecular weights. Keratin proteins have demonstrated that keratins can be separated into two classes, acidic and basic; and 19 different keratin polypeptides are distinguishable, $(8,21)$. Immunohistochemical findings on keratin distribution in human salivary glands have been obtained with the use of polyclonal antikeratin antiserum and some monoclonal antibodies $(3,4,11,14-17)$, however no studies have appeared on the immunohistochemical detection of specific keratin polypeptides using monoclonal antibodies in the normal salivary glands.

Human salivary glands are composed of acinar compartments and ductal segments including intercalated, striated, and excretory ducts. All previous reports 
have stated ductal epithelium to be positive for keratin proteins; and some studies have found keratin in myoepithelial cells as well $(5,7)$. Intercalated duct cells have been implicated in the histogenesis of salivary gland tumors (23) and reserve cells or ductal basal cells located in the ductal system also seem to be important possible progenitor cells $(1,20)$. However, conclusive evidence for the cell type responsible has not been given in terms of cytoskeletal protein immunohistochemistry. In attempts to find the originator cells of salivary gland tumors, various workers have examined immunohistochemical markers in ductal segments or in myoepithelial and other limited cells of the normal salivary gland.

The present study was undertaken to explore with a panel of monoclonal antibodies the spectra of keratin polypeptides specifically expressed in intercalated duct cells and ductal basal cells of normal human salivary glands, because two cells are suspected to be probable progenitor cells of salivary gland tumors.

\section{MATERIALS AND METHODS}

A total of 16 cases of normal human salivary glands (6 parotid and 10 submandibular glands) were obtained by surgical procedure. They were divided into two portions; one was fixed in Carnoy's solution, and the other in 10\% formalin.

Carnoy's-Fixed Group: The tissue specimens were fixed in Carnoy's solution for $6 \mathrm{hr}$ and then embedded in paraffin.

Formalin-Fixed Group: The specimens were fixed in $10 \%$ formalin for $12 \mathrm{hr}$ at room temperature and then embedded in paraffin.

Immunohistochemical Method

Sixteen anti-keratin antibodies (monoclonal) and polyclonal anti-keratin antiserum were employed. Immunogens, keratin types as nos or molecular weights (KDs), dilution and method and product names are tabulated in Table 1.

With the monoclonal antibodies used, immunohistochemical detection of keratin polypeptides covered nos. 1, 5, 6, 7, 8, 10,11,13,16,17, 18, and 19 keratins and molecular weights ranging from $40 \mathrm{KDs}$ (no. 19) to $68 \mathrm{KDs}$ (no. 1).

\section{RESULTS}

\section{Comparison of keratin distribution between Carnoy's- and formalin-fixed sections}

Carnoy's-fixed tissue sections showed stronger reactions for the immunohistochemical localization of keratins in normal salivary glands. However, in Carnoy's-fixed sections, the staining reactions with monoclonal antibodies, PKK1 was markedly reactive to ductal basal cells, whereas PKK2, RPN1161, RPN1163, and RPN1166 were negative. Formalin-fixed specimens were selectively positive with monoclonal antibodies, KL1, PKK1, RGE53, RPN1164, RPN1165 and were unreactive with the other monoclonal antibodies used (Table 2). No differences of immunohistochemical stainings for keratins were given in the ductal system of the parotid and submandibular glands.

Staining patterns obtained with various antibodies

Polyclonal anti-keratin antiserum (TK): This antiserum reacted with 41-65 KDs keratins. Almost all normal salivary gland ducts were positive for "TK" keratins; striated duct epithelium and their basal cells were positive in Carnoy's-fixed 
TABLE 1. Immunohistochemical detection of monoclonal antibodies for keratins

\begin{tabular}{|c|c|c|c|c|}
\hline & Immunogens & $\begin{array}{l}\text { Keratin type } \\
\text { no. of MW }\end{array}$ & Dilution & Products \\
\hline TK & $\begin{array}{l}\text { human sole epithelium } \\
\text { (st. corneum) }\end{array}$ & $41-65 \mathrm{D}$ & $1 / 40$ & $\begin{array}{l}\text { Dakopatts } \\
\text { (Copenhagen) }\end{array}$ \\
\hline $\mathrm{KL} 1$ & $\begin{array}{l}\text { human keratinized } \\
\text { squamous epithelium }\end{array}$ & $55-57 \mathrm{KD}$ & $1 / 80$ & $\begin{array}{l}\text { Immunoteck } \\
\text { (Marsille) }\end{array}$ \\
\hline PKK1 & pig kidney epithelium & $\begin{array}{c}40,45,52.5 \mathrm{KD} \\
\text { no. } 19,18,8\end{array}$ & $1 / 80$ & $\begin{array}{l}\text { Labsystems } \\
\text { (Helsinki Finland) }\end{array}$ \\
\hline PKK2 & pig kidney epithelium & $\begin{array}{c}40,46,48,54 \mathrm{KD} \\
\text { no. } 19,17,16,7\end{array}$ & $1 / 80$ & $\begin{array}{l}\text { Labsystems } \\
\text { (Helsinki Finland) }\end{array}$ \\
\hline PKK3 & pig kidney epithelium & $\begin{array}{l}45 \mathrm{KD} \\
\text { no. } 18\end{array}$ & $1 / 80$ & $\begin{array}{l}\text { Labsystems } \\
\text { (Helsinki Finland) }\end{array}$ \\
\hline RGE53 & Hela cells & no. 18 & $1 / 20$ & $\begin{array}{l}\text { Euro-Diagnostic BV. } \\
\text { (Hollans) }\end{array}$ \\
\hline $\mathrm{K} 4.62$ & $\begin{array}{l}\text { Cultured human } \\
\text { breast carcinoma }\end{array}$ & no. 19 & $1 / 20$ & $\begin{array}{l}\text { Bio-Yeda } \\
\text { (Israel) }\end{array}$ \\
\hline $\mathrm{K} 8.12$ & $\begin{array}{l}\text { bovine epidermal } \\
\text { keratin }\end{array}$ & no. 13,16 & $1 / 20$ & $\begin{array}{l}\text { Bio-Yeda } \\
\text { (Israel) }\end{array}$ \\
\hline K8.13 & $\begin{array}{l}\text { bovine epidermal } \\
\text { keratin }\end{array}$ & $\begin{array}{c}\text { no. } 1,5,6,7,8 \text { (basic) } \\
\text { no. } 10,11,18 \text { (acidic) }\end{array}$ & $1 / 20$ & $\begin{array}{l}\text { Bio-Yeda } \\
\text { (Israel) }\end{array}$ \\
\hline $\mathrm{K} 8.60$ & $\begin{array}{l}\text { bovine epidermal } \\
\text { keratin }\end{array}$ & $\begin{array}{l}40-69 \mathrm{KD} \\
\text { no. } 10,11\end{array}$ & $1 / 20$ & $\begin{array}{l}\text { Bio-Yeda } \\
\text { (Israel) }\end{array}$ \\
\hline RPN1160 & PtK1 cell & no. 18 & $1 / 20$ & $\begin{array}{l}\text { Amersham } \\
\text { (Buckinghamshire). }\end{array}$ \\
\hline RPN1161 & $\begin{array}{l}\text { PT112 bladder } \\
\text { ca cell live }\end{array}$ & & $1 / 20$ & $\begin{array}{l}\text { Amersham } \\
\text { (Buckinghamshire) }\end{array}$ \\
\hline RPN1162 & $\begin{array}{l}\text { PT112 bladder } \\
\text { ca cell live }\end{array}$ & no. 7 & $1 / 20$ & $\begin{array}{l}\text { Amersham } \\
\text { (Buckinghamshire) }\end{array}$ \\
\hline RPN1163 & PtK1 cells & & $1 / 20$ & $\begin{array}{l}\text { Amersham } \\
\text { (Buckinghamshire) }\end{array}$ \\
\hline RPN1164 & $\begin{array}{l}\text { SV } 40 \text { transformed } \\
\text { human keratinocyte }\end{array}$ & no. 8 (type II) & $1 / 20$ & $\begin{array}{l}\text { Amersham } \\
\text { (Buckinghamshire) }\end{array}$ \\
\hline RPN1165 & $\begin{array}{l}\text { SV } 40 \text { transformed } \\
\text { human keratinocyte }\end{array}$ & no. 19 & $1 / 20$ & $\begin{array}{l}\text { Amersham } \\
\text { (Buckinghamshire) }\end{array}$ \\
\hline RPN1166 & PtK1 cells & no. 8 & $1 / 20$ & $\begin{array}{l}\text { Amersham } \\
\text { (Buckinghamshire) }\end{array}$ \\
\hline
\end{tabular}

specimens (Fig. 1).

KL1: Monoclonal antibody KL1 reacted with 55-57 KDs keratins. In salivary glands, lateral and basal borders of acinar cells and demilune cells of mucous acini and intercalated duct cells showed positive KL1 staining, and striated duct cells gave a marked reaction (Fig. 2).

PKK1: The monoclonal antibody PKK1 detected 40, 45, and $52.5 \mathrm{KDs}$ 
keratins (nos. 19, 18, and 8). Histochemical localization of "PKK1" keratin was different between Carnoy's- and formalin-fixed sections: acinar cells were negative in Carnoy's-fixed sections, but positive in formalin-fixed ones. Ductal epithelium of striated and excretory ducts was positive for PKK1 staining, and staining intensity was particularly strong in basal cells in Carnoy's-fixed sections (Fig. 3).

PKK2: All the sections were negative (40, 46, 48, $54 \mathrm{KDs}$; nos. 19, 17, 16, 7).

TABLE 2. Distribution patterns for monoclonal keratin antibodies in salivary gland and cystadenolymphoma

\begin{tabular}{|c|c|c|c|c|c|c|}
\hline & \multicolumn{3}{|c|}{ Acinar Compartment } & \multirow{2}{*}{$\frac{\text { Intercalated }}{\text { duct }}$} & \multicolumn{2}{|c|}{ Striated duct } \\
\hline & $\begin{array}{l}\text { Lateral } \\
\text { border }\end{array}$ & $\begin{array}{c}\text { Luminal } \\
\text { border }\end{array}$ & $\begin{array}{l}\text { Demillune cells } \\
\text { of mucous gland }\end{array}$ & & $\begin{array}{l}\text { duct } \\
\text { cells }\end{array}$ & $\begin{array}{l}\text { basal } \\
\text { cells }\end{array}$ \\
\hline TK & + & + & + & \pm & +1 & +1 \\
\hline KL1 & + & + & + & +1 & +2 & 0 \\
\hline PKK1 & 0 & 0 & 0 & 0 & +1 & $\begin{array}{l}+2-+3 \\
\text { (carnoy) }\end{array}$ \\
\hline PKK2 & 0 & 0 & 0 & 0 & 0 & 0 \\
\hline PKK3 & + & + & + & \pm & \pm & 0 \\
\hline RGE53 & + & + & + & \pm & +1 & 0 \\
\hline $\mathrm{K} 4.62$ & 0 & 0 & $+1-+2$ & +2 & +1 & +2 \\
\hline K8.12 & 0 & 0 & +1 & +1 & +1 & $+2-+3$ \\
\hline $\mathrm{K} 8.13$ & 0 & 0 & 0 & \pm+2 & $+1-2$ & 0 \\
\hline $\mathrm{K} 8.60$ & 0 & 0 & 0 & \pm-+1 & \pm-+1 & 0 \\
\hline RPN1160 & + & + & + & +1 & \pm-+1 & 0 \\
\hline RPN1161 & 0 & 0 & 0 & 0 & 0 & 0 \\
\hline RPN1162 & $0- \pm$ & $0- \pm$ & $0- \pm$ & $0- \pm$ & $0- \pm$ & $0- \pm$ \\
\hline RPN1163 & 0 & 0 & 0 & 0 & 0 & 0 \\
\hline RPN1164 & \pm & \pm & \pm & +2 & $+1-+2$ & 0 \\
\hline RPN1165 & \pm & \pm & \pm & \pm & +1 & +2 \\
\hline RPN1166 & 0 & 0 & 0 & 0 & 0 & 0 \\
\hline
\end{tabular}

0 ; negative, ; trace, +1 ; slight, +2 ; moderate, +3 ; strong

Immunohistochemical detection of keratin prateins with the use of monoclonal antibodies in human submandibular glands $(\times 150)$

FIG. 1. TK staining in excretory duct. Ductal basal cells react strongly for TK staining, and ductal epithelial cells also bind.

FIG. 2. KL1 staining in striated and intercalated ductal cells, and serous acinar cells show positive deposition. Particularly abundance in striated duct cells.

FIG. 3. Pkk1 staining is restricted in basal cells of ductal epithelium.

Fig. 4. RGE 53 staining is present in striated ducts and acinar cells, and in intercalated duct cells in a very slight amount.

FIG. 5. Monoclonal antibody K4.62 staining is positive in intercalated and striated ductal cells, and shows the highest reaction in both basal and intercalated duct cells.

Fig. 6. and 7. Monoclonal antibody $\mathrm{K} 8.12$ reaction. Reaction product is concentrated in intercalated duct cells (Fig. 6), and ductal basal cells (Fig. 7). 


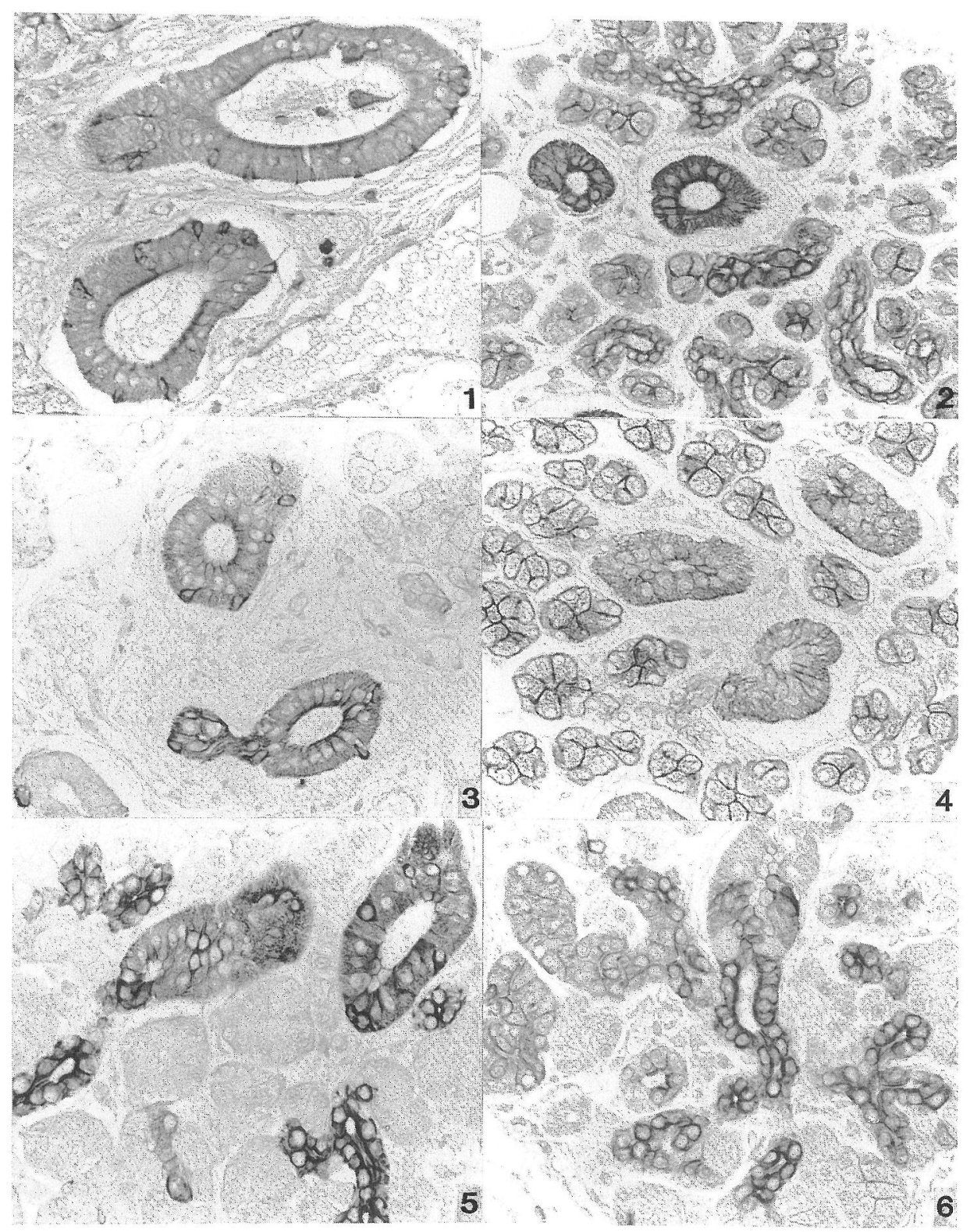




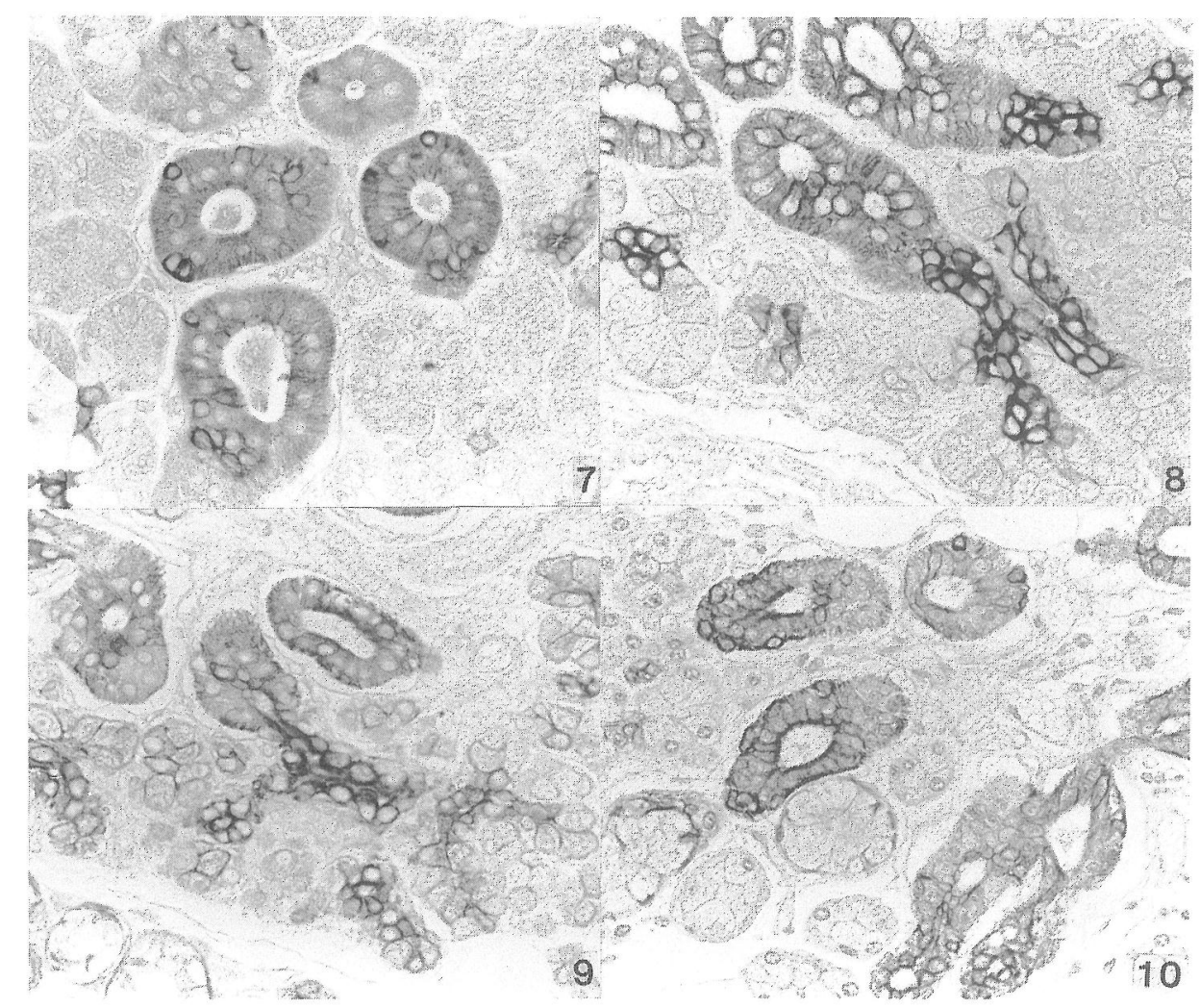

FIG. 8. K8.13 reaction is moderate in intercalated duct cells and less positive in striated duct cell. FIG. 9. RPN 1164 staining is conspicuous in intercalated duct cells and slight-to-moderately positive in striated duct cells.

FIG. 10. RPN 1165 staining is present in intercalated and striated duct cells, positive in limited basal cells of striated duct.

PKK3: Monoclonal antibody PKK3 bound to $45 \mathrm{KD}$ keratin (no. 18). Salivary glands indicated slight PKK3 staining in the lateral and luminal borders of acinous compartments, and in striated and intercalated duct cells.

RGE53: Monoclonal antibody RGE53 detected no. 18 keratin. In the normal gland, the border zone of the acinar cell was positive, the intercalated duct cells gave trace staining and striated duct cells were moderately positive (Fig. 4).

K4.62: This monoclonal antibody reacted with no. 19 keratin. Serous acinar cells lacked K4.62 keratin, but demilune cells in submandibular glands were positive. Intercalated duct cells and ductal basal cells showed a particular abundance of K4.62, and striated duct cells were also positive (Fig. 5).

K8.12: Monoclonal antibody $\mathrm{K} 8.12$, detected no. 13 keratin polypeptide. Monoclonal K8.12 reagent bound to demilune cells of acinar elements: it gave positive staining in intercalated and striated ducts and conspicuous staining in ductal basal cells (Figs. 6, 7). 
K8.13: This monoclonal antibody reacted with a wide range of keratins, nos. 1, 5, 6, 7, 8 (basic) and 10, 11, 18 (acidic). Monoclonal antibody K8.13 stained intercalated duct and striated duct cells at a comparatively high level, but it did not bind to acinar cells (Fig. 8).

K8.60: Monoclonal antibody K8.60 reacted with keratin nos. 10 and 11 (40 and $69 \mathrm{KDs}$ ). This monoclonal antibody was weakly reactive with intercalated and striated duct cells of the normal gland.

RPN1160: This monoclonal antibody bound to no. 18 keratin. Acinar compartments of serous acinar cells showed positive staining in the lateral and basal borders of acini and in demilunes, and intercalated and striated duct cells indicated a low reaction.

RPN1161: No reaction product was detected.

RPN1162: Monoclonal antibody RPN1162 detected no. 7 keratin. Acinar and ductal components of salivary glands exhibited a very slight staining of this keratin.

RPN1163: No staining was obtained.

RPN1164: Monoclonal antibody RPN1164 reacted with no. 8 keratin. Acinar compartments of normal salivary glands displayed trace or very slight staining with this monoclonal antibody, and intercalated and striated duct cells displayed slight-tomoderate staining (Fig. 9).

RPN1165: Monoclonal antibody RPN1165 bound to no. 19 keratin protein. Lateral border and basal aspect of serous acinar cells, demilune cells (submandibular gland) and intercalated duct cells were traceably or slightly reactive; in the striated duct, ductal cells were slightly reactive and basal cells were moderately reactive (Fig. 10).

RPN1166: Monoclonal antibody RPN1166 reacted with no. 8 keratin, but it did not bind to any of the tissue components.

\section{DISCUSSION}

Intercalated duct cells of the human salivary gland are thought to be the probable progenitor of salivary gland tumors, and reserve cells or ductal basal cells in the ductal segments may also give rise to such tumors $(1,20)$. Intercalated duct cells have unique properties as bipolar functions of differentiation or transformation. Histochemically specific markers of two progenitor cells are unknown. With regard to the immunohistochemical aspects of salivary glands, Ramaekers et al. (19) pointed out that monoclonal keratin antibody RGE53 reacted with pleomorphic adenoma cells. Von Muijen et al. (24) noted that the monoclonal anti-keratin antibody produced by clone 77 reacted positively with ductal cells, while that produced by clone 80 bound to both ductal and acinar cells of the parotid gland. Gown and Vogel (10) also studied two monoclonal anti-keratin antibodies and reported that 34 E12 reacted markedly with intercalated and striated duct cells, while $35 \mathrm{H} 11$ stained acinar and ductal cells equally.

In the present study, monoclonal antibodies K4.62, K8.13 and RPN1164 gave a more marked reaction in intercalated duct cells than in striated duct cells. Other antikeratin antibodies, KL1, K8.12, K8.60, and RPN1160, were also reactive with intercalated duct cells, but to a slightly lesser extent. Based on these immunohistochemical findings, intercalated duct cells appear to contain no. 19 (K4.62); 
nos. 1, 5, 6, 7, 8, 10, 11, 18 (K8.13, K8.60, RPN1160, RPN1164); and no. 13, 16 (K8.12) keratins; as well as 55-57 KDs keratins (KL1). PKK1 (nos. 8, 18, 19) and TK (polyclonal) also bound to ductal basal cells of striated or excretory ducts. Thus keratin expressions in intercalated duct cells were not so specific.

Details of morphology in salivary gland ductal cells have been described (18), that is, striated ducts composed of two cell types; light and dark cells or light cells and/or basal cells, of three cell types; light, dark and basal cells, and of four cell types; light, dark and two types of basal cells. It is also reported that excretory ductal cells were extremely variable in shape, flattened, cuboidal, columnar and pseudostratified epithelial cells, and they were also composed of basal cells. Basally located cells in striated and/or excretory ducts of salivary glands have been reported to be reactive with polyclonal anti-keratin antiserum, which detects a wide spectrum of keratins (41$65 \mathrm{KDs})$. Our preceding paper noted that basal cells of salivary gland ducts in the guinea pig and monkey, and of striated and excretory ducts in the horse and pig, were positively stained for keratin (22). Immunohistochemical identification of keratin proteins in ductal basal cells has reported that strong staining for monoclonal antibody LICR-LON-16a was recognized in those cells (reserve cells) (12). Geiger et al. (9) noted that positive reactions with monoclonal anti-keratin antibodies KG8.13 (nos. 1, 5, 6, 7, 8, 18), KM4.62 (no. 19), KS 18.18 (no. 18), KA-1 (nos. 4, 5, 6), and with KS858 (nos. 13, 16) were noted in basal cells of the duct. Recently, Dardick et al. (6) described ductal basal cells of parotid glands decorated moderately to strongly with 312C8-1 and K8.12, and myoepithelial cells were positive to HHF35 (muscle specification). Born et al. (2) stated that monoclonal keratin antibody KS8.58 (nos. 13, 16) existed specifically in ductal basal cells. It has been suggested that basal cells of the salivary gland ducts are the progenitor cells of various tumors, as well as of other proliferative disorders $(2,5,6,9,12)$.

In the present study, basal cells of salivary gland ducts expressed keratins detected by antibodies PKK1 (Carnoy's fixed section), K4.62, K8.12 and RPN1165 (formalin fixed section) which bind to nos. 19, 18, 16, 13 and 8 keratins, and common keratin subclass no. 19 or nos. 16, 13 might be specially expressed in ductal basal cells. Markers of keratin proteins using monoclonal antibodies were reported in ductal basal cells, whereas a wide spectrum of keratin peptides were also noted in intercalated duct cells of salivary glands. The present finding in keratin expression of ductal basal cells in the normal salivary glands might be evaluated to be compared with those of salivary gland tumors.

\section{ACKNOWLEGEMENT}

This investigation was supported partially by Miyata Research Fund.

\section{REFERENCES}

1. Batsakis, J. G.: Salivary gland neoplasia: an outcome of modified morphogenesis and cytodifferentiation. Oral Surg. 49; 229-232, 1980.

2. Born, I. A., Schwechheimer, K., Maier, H. and Otto, H. F.: Cytokeratin expression in normal salivary glands and in cystadenolymphomas demonstrated by monoclonal antibodies against selective cytokeratin polypeptides. Virchows Arch. A (Pathol. Anat.) 411; 583-589, 1987. 
3. Caselitz, J., Löning, T., Staquet, M.J., Seifert, G. and Thivolet, J.: Immunocytochemical demonstration of filamentous structures in parotid gland. J. Cancer Res. Clin. Oncol. 100; 5968, 1981.

4. Caselitz, J., Osborn, M., Seifert, G. and Weber, K.: Intermediate-sized filament proteins (prekeratin, vimentin, desmin) in the normal parotid gland and parotid gland tumours. Immunofluorescence study. Virchows Arch. A (Pathol. Anat.) 393; 273-286, 1981.

5. Caselitz, J., Walther, B., Wustrow, J., Seifert, G., Weber, K. and Osborn, M.: A monoclonal antibodies that detects myoepithelial cells in exocrine glands, basal cells in other epithelia and basal and superbasal cells in certain hyperplastic tissues. Virchow Arch. A (Pathol. Anat.) 409; 725-7;38, 1986.

6. Dardick, I., Parks, W. R., Little, J. and Brown, D. L.: Characterization of cytoskeletal proteins in basal cells of human parotid salivary gland duct. Virchow Arch. A (Pathol. Anat. Histopathol.) 412; 525-532, 1988.

7. Franke, W. W., Schmid, E., Freudenstein, C., Appelhans, B., Osborn, M., Weber, K. and Keenan, T. W.: Intermediate-sized filaments of the prekeratin type in myoepithelial cells. $J$. Cell Biol. 84; 633-654, 1980.

8. Fuchs, E., Grace, M. P., Kim, K. H. and Marchuk, D.: Differential expression of two classes of keratins in normal and malignant epithelial cells and their evolutionary conservation. Cancer cells 1 ; 101-146, 1984.

9. Geiger, S., Geiger, B., Leitner, O. and Marshak, G.: Cytokeratin polypeptides expression in different epithelial elements of human salivary glands. Virchows Arch. A (Pathol. Anat.) 410; 403-414, 1987.

10. Gown, A. M. and Vogel, A. M.: Monoclonal antibodies to human intermediate filament proteins II. Distribution of filament proteins in normal human tissues. Am. J. Pathol. 114; 309321,1984

11. Hosaka, M., Tatemoto, Y., Kawamura, K. and Mori, M.: Immunohistochemical evaluation of different filament proteins in human salivary glands. Acta histochem. cytochem. 18; 504-514, 1985.

12. Knight, J., Gusterson, B., Jones, R. R., Landells, W. and Wilson, P.: Monoclonal antibodies specific for subsets of epidermal keratins: Biochemical and immunocytochemical characterization-Applications in pathology and cell culture. J. Pathol. 145; 341-354, 1985.

13. Moll, R., Frank, W. W. and Schiller, D. L.: The catalog of human cytokeratins: Patterns of expression in normal epithelia, tumors and cultured cells. Cell 31; 11-24, 1982.

14. Mori, M., Murase, N., Hyun, K. H., Sumitomo, S. and Kawamura, K.: Immunohistochemical studies of keratin distribution in salivary gland tumors. Acta histochem. cytochem. 18; 21-32, 1985.

15. Mori, M., Sumitomo, S., Iwai, Y. and Meenagham, M. A.: Immunolocalization of keratins in salivary gland pleomorphic adenoma using monoclonal antibodies. Oral Surg. 61; 611-616, 1986.

16. Mori, M., Tsukitani, K., Ninomiya, T. and Okada, Y.: Various expression of modified myoepithelial cells in salivary pleomorphic adenoma. Immunohistochemical studies. Path. Res. Pract. 182; 632-646, 1987.

17. Nathrath, W. B. J., Wilson, P. D. and Trejdosiewicz, L. K.: Immunohistochemical localization of keratin and luminal epithelial antigen in myoepithelial and luminal epithelial cells of human mammary and salivary gland tumours. Path. Res. Pract. 175; 279-288, 1982.

18. Pinkstaff, C. A.: The cytology of salivary glands. Int. Rev. cytol. 63; 141-261, 1980.

19. Ramaekers, F., Huysmans, A., Moesker, O., Kant, A., Jap, P., Herman, C. and Vooijs, P.: Monoclonal antibody to keratin filaments specific for glandual epithelia and their tumors. Use in surgical pathology. Lab. Invest. 49; 353-361, 1983.

20. Regezi, J. A. and Batsakis, J. G.: Histogenesis of salivary gland neoplasms otolaryngol. Clin. North Am. 10; 297-307, 1977. 
21. Sun, T. T., Eichner, R., Schermer, A., Cooper, D., Nelson, W. G. and Weiss, R. A.: Classification, expression and possible mechanisms of evoluture of mammalian epithelial keratins: A unifying model. Cancer Cells 1; 169-176, 1984.

22. Takai, Y., Noda, Y., Sumitomo, S., Kawamura, K. and Mori, M.: Immunohistochemical detection of keratin proteins in salivary gland ducts of mammals. Acta histochem. cytochem. 18; 353-361, 1985.

23. Thackray, A. C. and Lucas, R. B.: Atlas of tumor pathology. Tumors of the major salivary glands. Second series Fascicle 10. Washington, D.C.: Armed Forces Institute of Pathology, 1974.

24. von Muijen, G. N. P., Ruiter, D. J., Ponec, M., 1974., Huiskens-Van der May, G. and Warnaar, S. O.: Monoclonal antibodies with different specificities against cytokeratins. An immunohistochemical study of normal tissues and tumors. Am. J. Pathol. 114; 9-17, 1984. 